\title{
Effect of Zr Additions on Non-Metallic Inclusions in X11CrNiMo12 Steel
}

\author{
Jaka Burja ${ }^{1, *}$, Mitja Koležnik ${ }^{2}$, Barbara Šetina Batič ${ }^{1}$ and Jožef Medved ${ }^{3}$ \\ 1 Institute of Metals and Technology, Lepi pot 11, SI-1000 Ljubljana, Slovenia; barbara.setina@imt.si \\ 2 Metal Ravne d.o.o., Koroška cesta 14, SI-2390 Ravne na Koroškem, Slovenia; mitja.koleznik@metalravne.com \\ 3 Department of Materials and Metallurgy, Faculty of Natural Sciences and Engineering, University of \\ Ljubljana, Aškerčeva cesta 12, SI-1000 Ljubljana, Slovenia; jozef.medved@ntf.uni-lj.si \\ * Correspondence: jaka.burja@imt.si; Tel.: +386-4701-981
}

Received: 22 July 2020; Accepted: 31 August 2020; Published: 2 September 2020

check for updates

\begin{abstract}
The production of clean steel is associated with high-quality steel grades for demanding applications. The formation of oxide inclusions mainly depends on the deoxidation practice; it is usually carried out through $\mathrm{Al}$ additions, but alumina inclusions can have detrimental effects. An alternative zirconium inclusion modification was used in a creep-resistant steel to improve the cleanliness of laboratory-made steel. The thermodynamics behind the inclusion modification are presented, the reaction products are identified and the steel cleanliness improvement is quantified. The resulting influence of zirconium addition on non-metallic inclusions and mechanical properties is discussed. While the $\mathrm{Zr}$ additions drastically reduce the non-metallic inclusion size and area, additions above a certain amount result in the formation of zirconium nitrides that ultimately soften the martensitic steel due to the depletion of nitrogen in solid solution.
\end{abstract}

Keywords: clean steel; non-metallic inclusions; Zr addition; creep-resistant steel; microstructure

\section{Introduction}

The X11CrNiMo12 steel grade is a martensitic creep-resistant steel that is generally used for turbine blades and fittings in thermal power plants. The efficiency of thermal power plants depends on the steam operating temperature and pressure, which are limited by material properties [1]. The creep-resistant 9-12\% Cr martensitic steels have proven to be reliable in withstanding high pressures and temperatures, therefore they are the most widely used steels in power plants [2-6]. They offer the best combination of high creep strength, high resistance against thermal fatigue, high steam oxidation resistance and good manufacturability at relative low costs [7]. However, they must fulfil very high-quality standards concerning mechanical properties and microstructure. One of the very important factors is steel cleanliness, which means that the content, size, shape and distribution of non-metallic inclusions is restricted. The so-called "clean steel" production can be achieved by the control of steel melting, refining and casting [8]. The use of deoxidation agents is very important, as they set the conditions for the formation of oxide non-metallic inclusions, both during refining and casting. Deoxidation is usually carried out through $\mathrm{Al}$ additions, but alumina inclusions can have detrimental effects. $\mathrm{Al}_{2} \mathrm{O}_{3}$ inclusions frequently cluster in the liquid state, leading to submerged entry nozzle clogging during casting (inclusions that are between 1 and $20 \mu \mathrm{m}$ in diameter are the most detrimental for clogging), and an uneven distribution of hard brittle inclusions that will typically break during deformation. Furthermore, the combination of low bonding strength to the matrix during deformation leads to void creation and separation (debonding) [9-12].

Alternatively, deoxidation can also be performed with elements like zirconium, which can change the size, number and distribution of non-metallic inclusions [13]. Zirconium additions are known to 
modify manganese sulphide inclusion [14] by forming nuclei for the formation of smaller yet more numerous MnS, and they also promote the precipitation of small nitride, carbide and carbonitride particles that cause grain refinement [14-16], and reduce the grain growth during high temperature annealing [17] and in the heat-affected zone during welding $[18,19]$. Zirconium is known to reduce the size of oxide non-metallic inclusions, and improve their distribution in the steel matrix, thus improving steel cleanliness [20,21]. Zirconium oxides are also heterogeneous nucleation sites for austenite during solidification, therefore they inhibit $\delta$-ferrite formation [22]. This can be beneficial, as $\delta$-ferrite can be harmful to the final properties of high-chromium martensitic steels [23]. The present investigation was undertaken with the objective of determining the effect of $\mathrm{Zr}$ additions on the size, distribution and composition of inclusions in an Al-killed steel X11CrNiMo12 steel grade.

\section{Materials and Methods}

Experimental charges of $\mathrm{X} 11 \mathrm{CrNiMo12}$ steel were melted in an induction melting furnace with a protective inert Ar gas atmosphere. The three charges were produced by melting $9 \mathrm{~kg}$ of Al-killed X11CrNiMo12, minor additions of ferrochromium affine $(68 \mathrm{~g}, 70 \% \mathrm{Cr}, 0.1 \% \mathrm{C})$ and manganese metal $(9 \mathrm{~g}, 99.9 \% \mathrm{Mn})$ were added to compensate for the losses, and the melt was also deoxidized with $\mathrm{Al}$. The first charge was re-melted without $\mathrm{Zr}$ additions, the second charge (300 ppm Zr) was modified by adding $4.5 \mathrm{~g}$ zirconium $(99.8 \% \mathrm{Zr}$ ) and the third charge (700 ppm $\mathrm{Zr}$ ) was modified by adding $11 \mathrm{~g}$ zirconium. After the $\mathrm{Zr}$ addition, the melt was homogenized by strong induction melting for $3 \mathrm{~min}$. The melt was cast into $60 \times 60 \times 300 \mathrm{~mm}$ ingots. The cast ingots were air-cooled to room temperature. The ingot heads were cut off to remove the shrinkage and ensure ingot soundness. The ingots were then homogenized at $1180{ }^{\circ} \mathrm{C}$ for $6 \mathrm{~h}$ in a gas heating furnace without protective atmosphere. The homogenized ingots were hot forged into $30 \mathrm{~mm}$-diameter bars by a pneumatic forging hammer. After the hot forging, the samples were annealed in an electric box furnace at $720{ }^{\circ} \mathrm{C}$ for $2 \mathrm{~h}$. The forged rods were cut into $200 \mathrm{~mm}$ samples and heat treated for further mechanical testing. The heat treatment regime is given in Table 1 , and the heat treatments were done in electric box furnaces without a protective atmosphere. The samples were also taken for metallographic and automatic inclusion analysis. Metallographic analysis and the determination of the prior austenite grain size according to ASTM (American Society for Testing and Materials) E112 standard were done by light optical microscopy using an Olympus DP70 microscope (Olympus, Tokyo, Japan). The samples for optical microscopy were etched with Vilella's reagent $(5 \mathrm{~mL} \mathrm{HCl}+2 \mathrm{~g}$ Picric acid $+100 \mathrm{~mL}$ Ethyl alcohol) for 10 to $15 \mathrm{~s}$, and the samples for electron microscopy were only polished. The electron backscatter diffraction (EBSD) analysis, the automatic non-metallic inclusion analysis and energy dispersive spectroscopy (EDS) analysis were done by electron microscopy (Jeol, Tokyo, Japan) using a FEG-SEM Jeol-JSM6500F with an Oxford system HKL Channel 5 system. The automatic non-metallic inclusion analysis was done by INCA Feature, and the total analysis area for each sample was $8.42 \mathrm{~mm}^{2}$.

Table 1. Heat treatment regime.

\begin{tabular}{cccccc}
\hline Austenitization & Cooling & Tempering $\mathbf{1}$ & Cooling & Tempering 2 & Cooling \\
\hline $1045^{\circ} \mathrm{C} 4 \mathrm{~h}$ & oil & $660^{\circ} \mathrm{C} 4.5 \mathrm{~h}$ & air & $640^{\circ} \mathrm{C} 4.5 \mathrm{~h}$ & air \\
\hline
\end{tabular}

The chemical analysis of the steel samples was done by time-of-flight mass spectrometers (TOFMS) LECO CS600 (C and S) and LECO TC436 (N and O), Coupled Plasma-Optical Emission Spectrometers (ICP-OES) Varian 730-ES (Ti and Zr) and Optical Emission Spectroscopy (OES) ARL 3460 (Si, Mn, Cr, $\mathrm{Ni}, \mathrm{Mo}, \mathrm{V}$ and $\mathrm{Al}$ ).

Mechanical testing was done on a Zwick/Roell Z100 tensile test machine. Three round $55 \mathrm{~mm}$-long samples were made for each test according to EN ISO 6892-1:2019. The Brinell hardness was measured with a KB 3000 BVRZ Standalone hardness testing machine. 
Calculation of Gibbs free energies for the formation of aluminum oxide, zirconium oxide and zirconium nitride at different temperatures were made with Outotec's HSC 8.0 Chemistry Software.

\section{Results}

The resulting chemical composition of the samples is given in Table 2. The calculated zirconium yield is roughly $60 \%$. There was an increase in oxygen when $\mathrm{Zr}$ was added, which is due to reactions between $\mathrm{Zr}$ and oxygen in the protective atmosphere. There is also a minor increase of nitrogen, as $\mathrm{Zr}$ increases nitrogen solubility in the steel melt [24].

Table 2. Chemical analysis of the samples.

\begin{tabular}{ccccccccccccc}
\hline & $\mathbf{C}$ & $\mathbf{S i}$ & $\mathbf{M n}$ & $\mathbf{S}$ & $\mathbf{C r}$ & $\mathbf{N i}$ & $\mathbf{M o}$ & $\mathbf{V}$ & $\mathbf{A l}$ & $\mathbf{Z r}$ & $\mathbf{O}$ & $\mathbf{N}$ \\
\hline $0 \mathrm{Zr}$ & 0.11 & 0.23 & 0.71 & 0.0055 & 11.65 & 2.70 & 1.63 & 0.30 & 0.021 & $<0.001$ & 0.0058 & 0.033 \\
$300 \mathrm{Zr}$ & 0.11 & 0.22 & 0.73 & 0.0052 & 11.65 & 2.70 & 1.66 & 0.30 & 0.018 & 0.030 & 0.0088 & 0.034 \\
$700 \mathrm{Zr}$ & 0.11 & 0.22 & 0.72 & 0.0053 & 11.62 & 2.70 & 1.64 & 0.30 & 0.019 & 0.070 & 0.0085 & 0.034 \\
\hline
\end{tabular}

The microstructural analysis revealed that all samples consisted of tempered martensite, and the main difference was in the grain size. The $\mathrm{Zr}$ additions had refined the martensitic microstructure as shown in Figure 1. The light optical microscope analysis revealed that the samples with 0 and 300 ppm Zr have visible oxide inclusions, while the 700 ppm has only visible nitride inclusions.
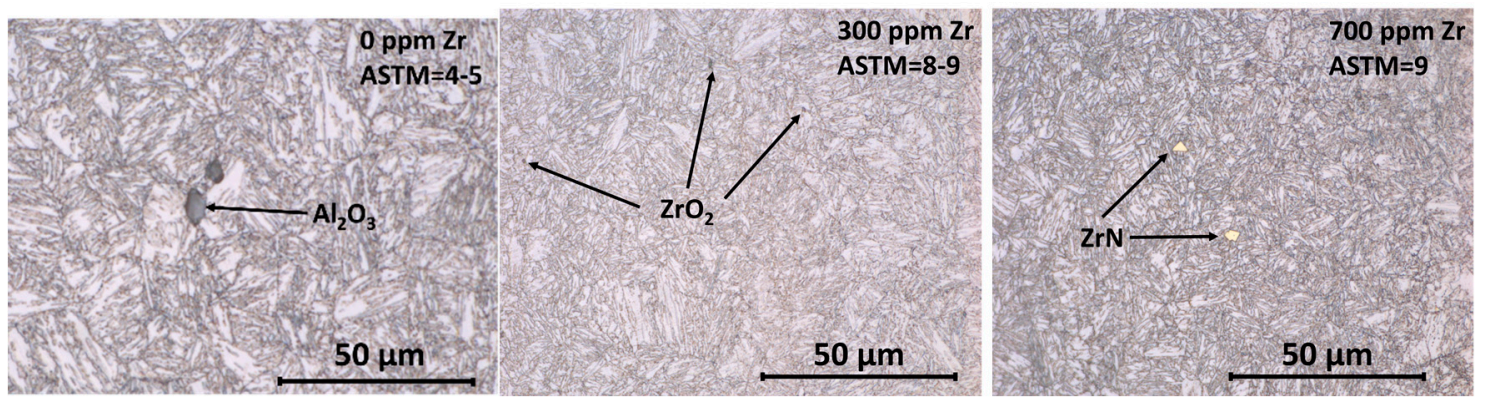

Figure 1. Microstructure of the samples with $0 \mathrm{ppm}, 300 \mathrm{ppm}$ and $700 \mathrm{ppm} \mathrm{Zr}$.

The SEM EBSD and EDS analysis of the representative non-metallic inclusions are presented in Figures 2-4. The sample without $\mathrm{Zr}$ contains typical Al-killed alumina inclusions with the occasional silicate and manganese sulphide (Figure 2). Fine zirconium oxide $\left(\mathrm{ZrO}_{2}\right)$ inclusions are dominant in the sample, with 300 ppm Zr (Figure 3). The sample with 700 ppm Zr (Figure 4) has a slight increase in the size of the inclusions, compared to the sample with $300 \mathrm{ppm} \mathrm{Zr}$, but this is mainly due to the formation of zirconium nitrides $(\mathrm{ZrN})$ on the $\mathrm{ZrO}_{2}$ nucleus. Although the oxides are still roughly the same size, the $\mathrm{ZrN}$ formation increases the total non-metallic inclusion area. The non-metallic inclusions were also analyzed by the EBSD technique that provides Kikuchi patterns. They were used for determining the inclusion crystal structure type. Figures 2-4 also show the Kikuchi patterns and crystal structure types for the three typical types of inclusions $\left(\mathrm{ZrN}, \mathrm{ZrO}_{2}\right.$ and $\left.\mathrm{Al}_{2} \mathrm{O}_{3}\right)$ found in the samples. The $\mathrm{ZrN}$ has a cubic face-centered crystal structure, while $\mathrm{ZrO}_{2}$ has a monoclinic structure and $\mathrm{Al}_{2} \mathrm{O}_{3}$ has a hexagonal close-packed structure. 

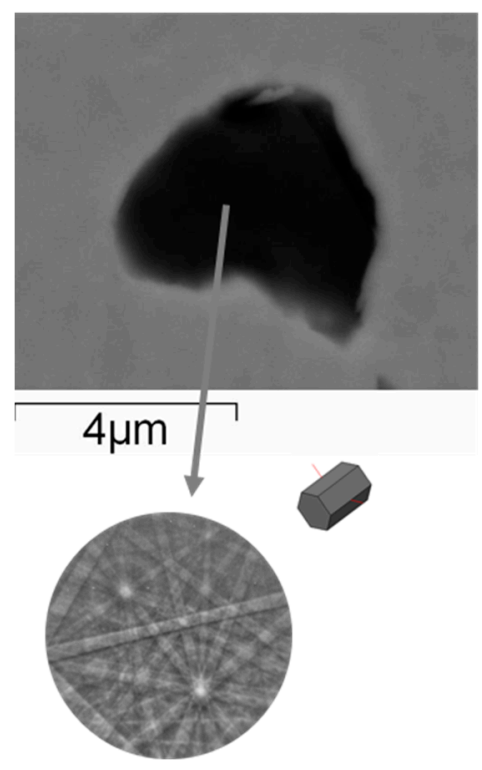
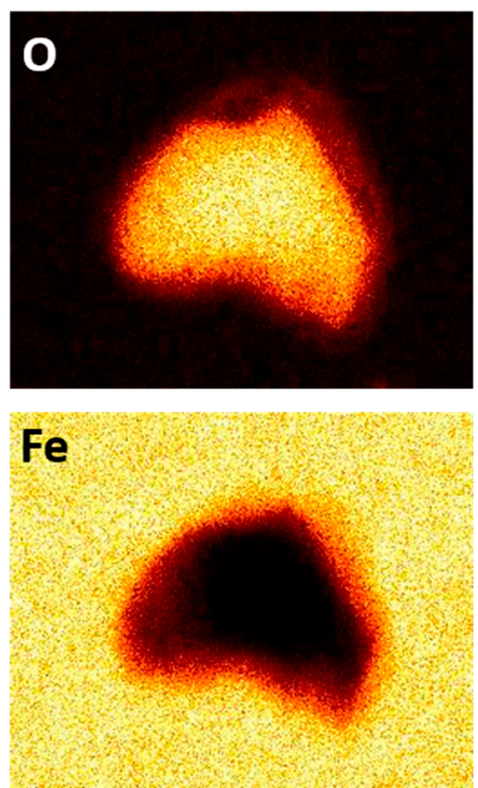
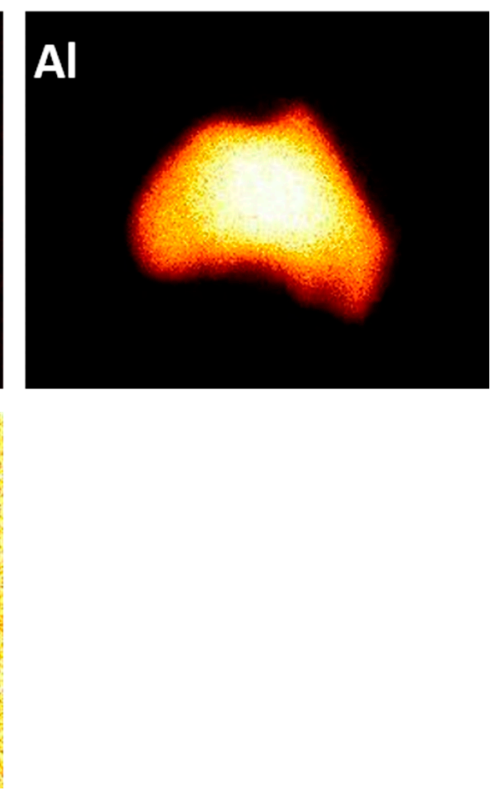

Figure 2. EDS mapping and the representative Kikuchi pattern of an $\mathrm{Al}_{2} \mathrm{O}_{3}$ non-metallic inclusion (corundum) in the sample without $\mathrm{Zr}$.
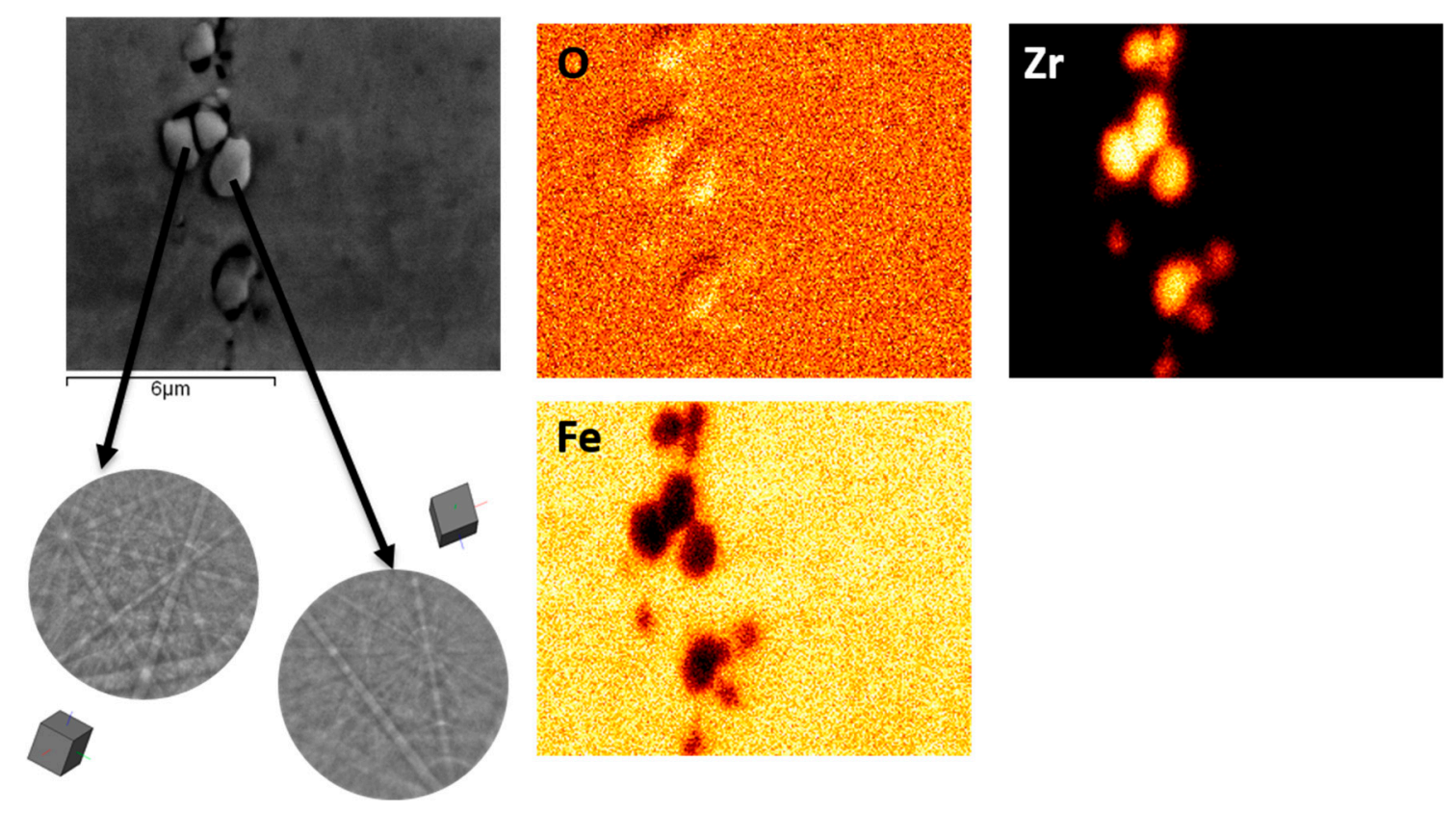

Figure 3. EDS mapping and representative Kikuchi pattern of a $\mathrm{ZrO}_{2}$ non-metallic inclusion (monoclinic) in the sample with 300 ppm Zr.

The inclusions were set into five categories- $\mathrm{Al}_{2} \mathrm{O}_{3}, \mathrm{MnS}, \mathrm{SiO}_{2}, \mathrm{ZrN}$ and $\mathrm{ZrO}_{2}$-based on their composition. The SEM automatic inclusion analysis showed that most of the inclusions are alumina-based in the non-modified sample. After the $\mathrm{Zr}$ addition, most of the inclusions become $\mathrm{ZrO}_{2}$ type. When additional $\mathrm{Zr}$ is added, $\mathrm{ZrN}$ appear in larger numbers, and the relative size also increases, as $\mathrm{ZrN}$ frequently form on previous $\mathrm{ZrO}_{2}$ inclusions (as shown in Figure 5). Complex inclusions such as $\mathrm{ZrN}$ formed on $\mathrm{ZrO}_{2}$, and were classified as $\mathrm{ZrN}$, as they presented the bulk of the non-metallic inclusion, as well as the matrix/inclusion phase boundary. 

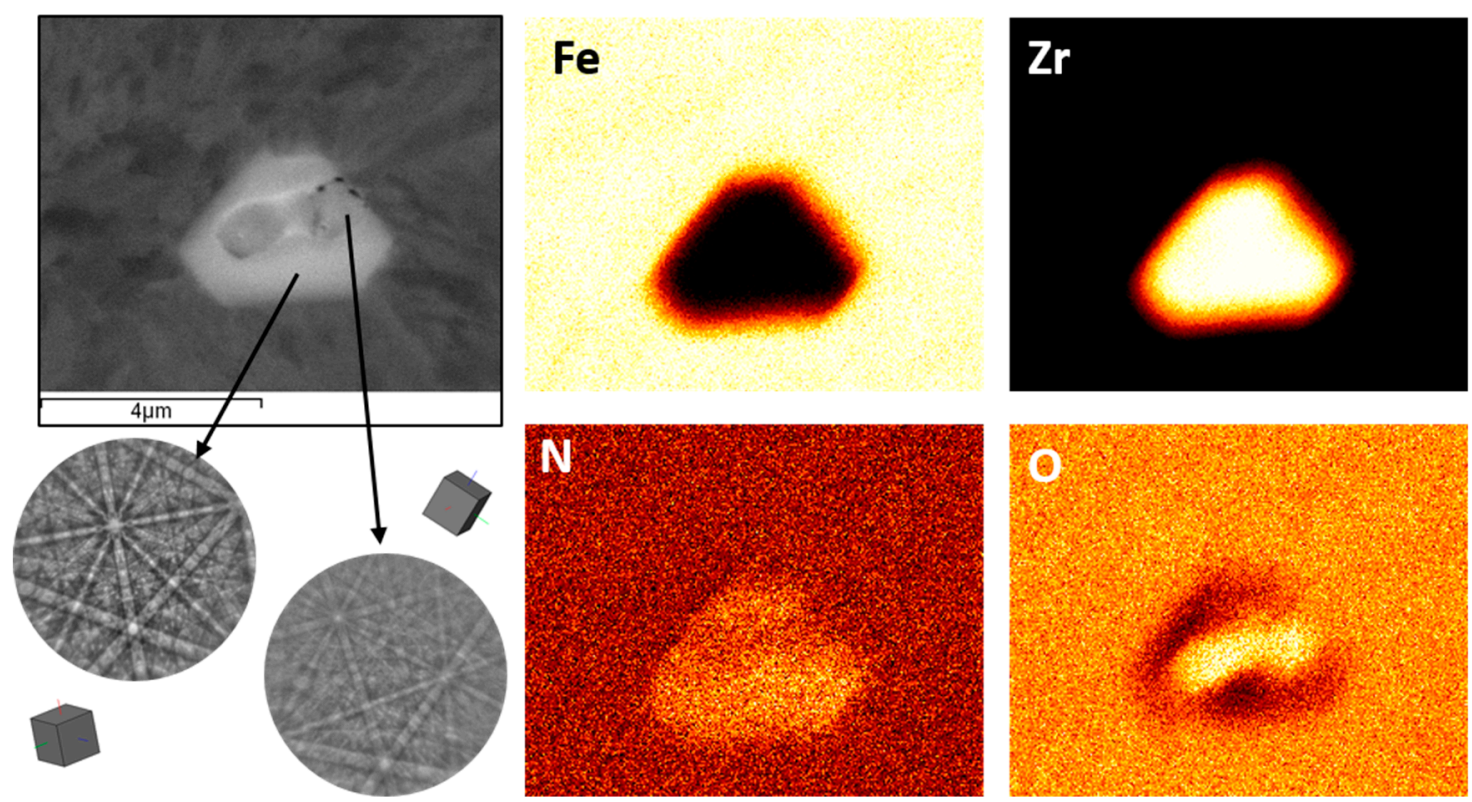

Figure 4. EDS mapping and Kikuchi pattern of a complex $\mathrm{ZrN}$ (cubic) and $\mathrm{ZrO}_{2}$ (monoclinic) non-metallic inclusion in the sample with $700 \mathrm{ppm} \mathrm{Zr}$.

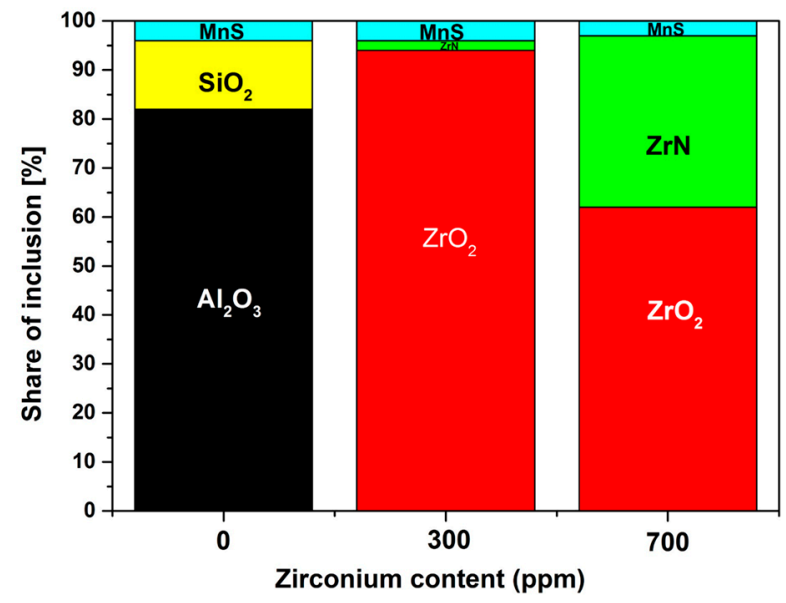

Figure 5. Type of inclusions at different $\mathrm{Zr}$ contents.

The SEM analysis revealed that zirconium drastically decreased the surface area of all non-metallic inclusion, as shown in Figure 6 (results of the Inca feature analysis). The dark inclusions are alumina and zirconium oxides, while the zirconium nitrides are seen as white inclusions.

The $\mathrm{Zr}$ additions promote the formation of numerous small homogeneously dispersed non-metallic inclusions. These results are in agreement with our previous work, where $\mathrm{Zr}$ was added to non-Al-killed steel [21]. One explanation for the formation of smaller $\mathrm{ZrO}_{2}$ non-metallic inclusions is that zirconium oxides require a lower critical radius for nucleation, as the result of low free Gibbs formation energy and low surface tension energy (better steel melt wettability), in comparison to alumina inclusions [25]. Another reason for the homogeneous distribution is the fact that during solidification, the $\mathrm{ZrO}_{2}$ particles are engulfed by the solidification front, while the alumina particles are pushed into the segregation bands by the solidification front [26].

The histogram of inclusions showed that the total area reduction is the result of a significant drop in the size of the inclusions. Figure 7 clearly shows that the largest share of inclusions modified by $\mathrm{Zr}$ is smaller than $1 \mu \mathrm{m}$. In the case of $300 \mathrm{ppm} \mathrm{Zr}$, over $80 \%$ of inclusions are smaller than $1 \mu \mathrm{m}$. This is in good agreement with the research of Karasov and Suito, where the majority of the $\mathrm{Zr}$ inclusions were less than $1 \mu \mathrm{m}$ in diameter $[27,28]$. 


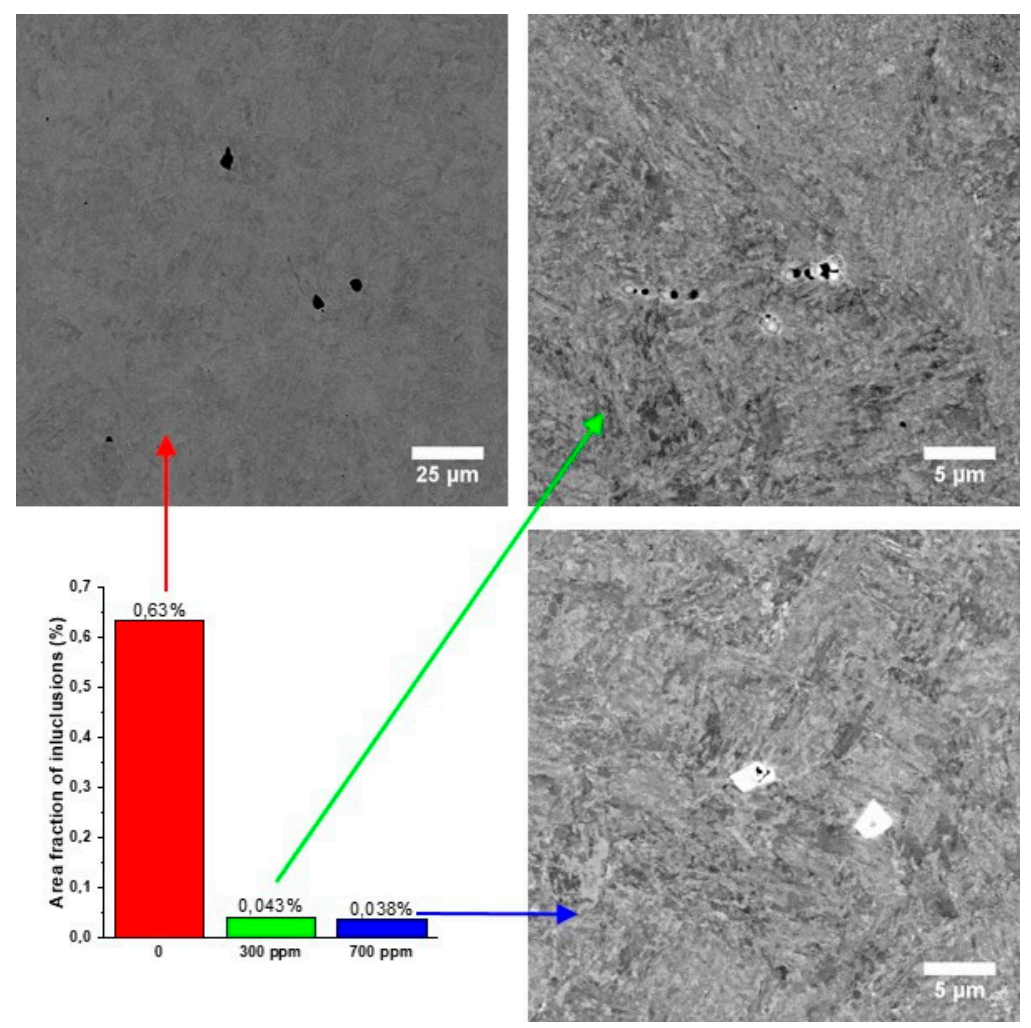

Figure 6. Area fraction covered by all non-metallic inclusions at different $\mathrm{Zr}$ contents and representative SEM images.

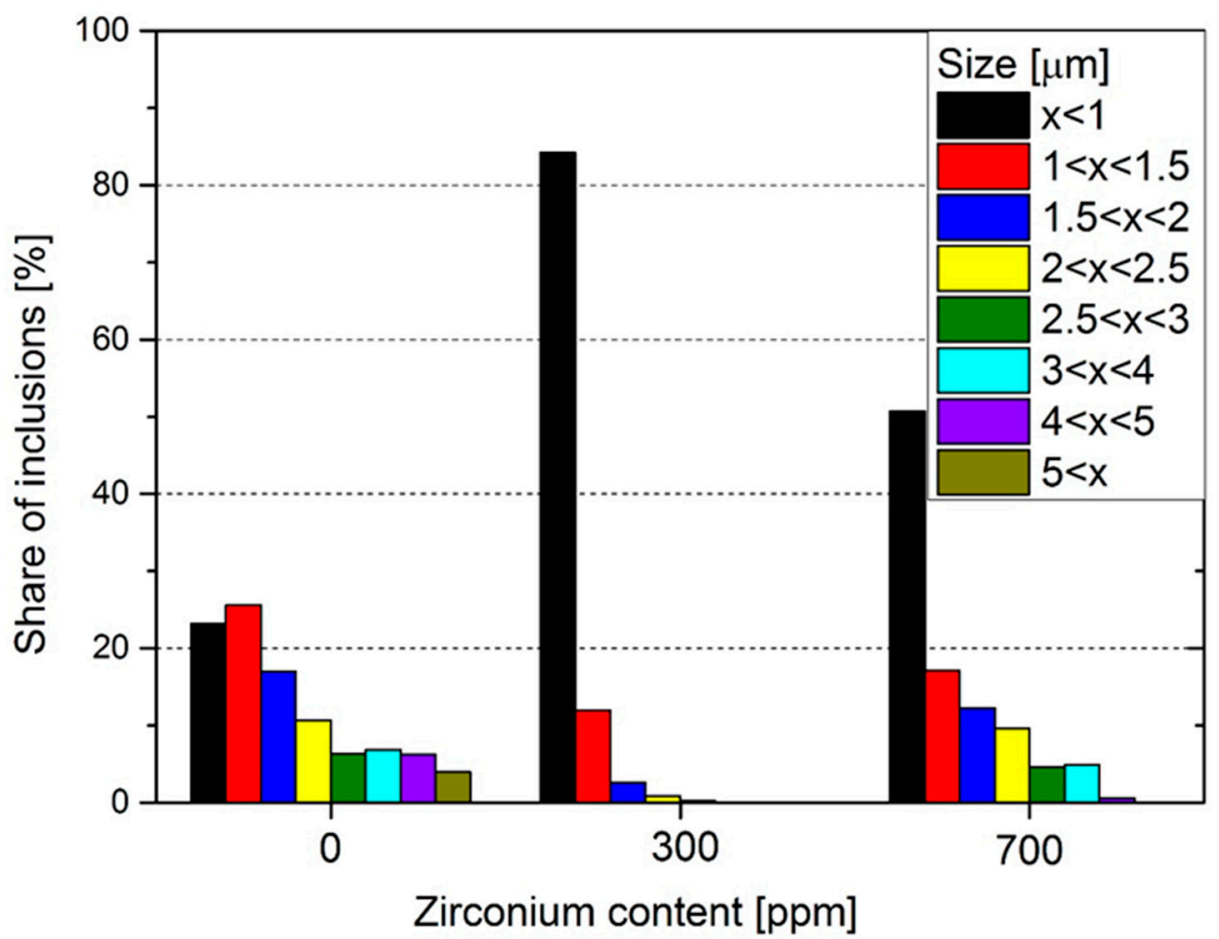

Figure 7. Share of non-metallic inclusion size for different $\mathrm{Zr}$ contents.

The results of the tensile test are presented in Table 3 (room temperature) and Table $4\left(500{ }^{\circ} \mathrm{C}\right.$ ). Surprisingly, there was no significant improvement in the mechanical properties after $\mathrm{Zr}$ additions. There was a slight improvement at $300 \mathrm{ppm} \mathrm{Zr}$, but tensile properties decreased at $700 \mathrm{ppm} \mathrm{Zr}$. This trend continues when the samples are tensile tested at $500^{\circ} \mathrm{C}$. 
Table 3. Mechanical properties at room temperature after heat treatment in Table 1.

\begin{tabular}{ccccc}
\hline & $\mathbf{R}_{\mathbf{p 0 2}} / \mathbf{M P a}$ & $\mathbf{R}_{\mathbf{m}} / \mathbf{M P a}$ & $\mathbf{A} / \%$ & Hardness HB \\
\hline $0 \mathrm{Zr}$ & $795 \pm 7$ & $1000 \pm 8$ & $15.4 \pm 0.8$ & $299 \pm 3$ \\
$300 \mathrm{Zr}$ & $796 \pm 6$ & $1010 \pm 6$ & $15.7 \pm 0.5$ & $302 \pm 2$ \\
$700 \mathrm{Zr}$ & $784 \pm 8$ & $985 \pm 8$ & $16.2 \pm 0.9$ & $298 \pm 3$ \\
\hline
\end{tabular}

Table 4. Mechanical properties at $500{ }^{\circ} \mathrm{C}$ after heat treatment in Table 1.

\begin{tabular}{cccc}
\hline & $\mathbf{R}_{\mathbf{p} 02} / \mathbf{M P a}$ & $\mathbf{R}_{\mathbf{m}} / \mathbf{M P a}$ & $\mathbf{A} / \%$ \\
\hline $0 \mathrm{Zr}$ & $585 \pm 5$ & $681 \pm 7$ & $21.3 \pm 1.2$ \\
$300 \mathrm{Zr}$ & $605 \pm 5$ & $688 \pm 6$ & $22.7 \pm 1.3$ \\
$700 \mathrm{Zr}$ & $584 \pm 6$ & $671 \pm 5$ & $23.0 \pm 1.3$ \\
\hline
\end{tabular}

The slight increase in mechanical properties can be attributed to the decrease in grain size. The subsequent fall in tensile strength in the $700 \mathrm{ppm} \mathrm{Zr}$ sample and the minimal increase in the $300 \mathrm{ppm} Z \mathrm{Zr}$ sample can be attributed to the loss of the precipitation hardening effect caused by small submicron nitride precipitates such as $\mathrm{V}(\mathrm{C}, \mathrm{N})$ and the formation of micron-sized ZrN during solidification, preventing their formation during heat treatment. The precipitation hardening effect is more effective when the precipitates are a couple of nanometers in size [29]. The multitude of Zr-based sharp edged inclusions, both oxide and nitride, probably decrease the mechanical properties due to the notch effect and subsequent void formation. Therefore, it can be concluded that the zirconium additions should be lower than $0.07 \%$ to prevent extensive nitride formation, and the weakening of the precipitation hardening effect during tempering.

The diagram with Gibbs free energy for the formation of $\mathrm{Al}_{2} \mathrm{O}_{3}, \mathrm{ZrN}$ and $\mathrm{ZrO}_{2}$ at $1600{ }^{\circ} \mathrm{C}$ in liquid $\mathrm{X} 11 \mathrm{CrNiMo12}$ steel for various zirconium contents is shown in Figure 8. The reason behind the modification effect of zirconium is the low Gibbs free energy for the formation of $\mathrm{ZrO}_{2}$. When adding elements like $\mathrm{Zr}$, the basic thermodynamic reactions must be considered, the yield strongly depends on reactions with oxygen. Zirconium has a high affinity to oxygen, and at around $50 \mathrm{ppm}$ of $\mathrm{Zr}$ it starts to be more reactive than the $200 \mathrm{ppm} \mathrm{Al}$ in steel (Figure 8). The high affinity to oxygen is one of the reasons why so much zirconium is present in non-metallic inclusions. The exact thermodynamic values were taken from Outotec HSC 8.0 Chemistry Software at $1600^{\circ} \mathrm{C}$, and the interaction coefficients in dilute $\mathrm{Fe}(\mathrm{l})$ and the Gibbs free energy changes due to the solution in liquid iron in wt.\% were taken from Sigworth et al. [30]. Furthermore, Figure 8 clearly shows that $\mathrm{ZrN}$ nitride non-metallic inclusions become more stable as the $\mathrm{Zr}$ content increases. This is why the $\mathrm{ZrN}$ content is low in the sample with $300 \mathrm{ppm} \mathrm{Zr}$ and high in the sample with $700 \mathrm{ppm} \mathrm{Zr}$, and in addition, the active oxygen content is lowered due to oxide formation, which further promotes nitride formation.

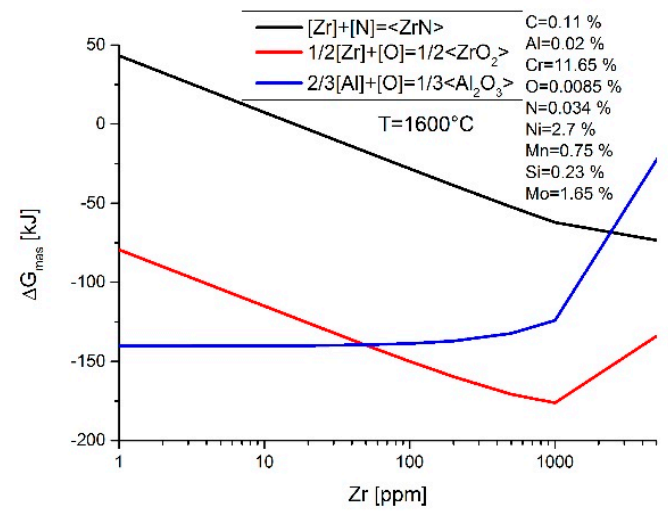

Figure 8. Gibbs free energy for the formation of $\mathrm{Al}_{2} \mathrm{O}_{3}, \mathrm{ZrO}_{2}$ and $\mathrm{ZrN}$ at $1600{ }^{\circ} \mathrm{C}(1873 \mathrm{~K})$ in liquid X11CrNiMo12. 


\section{Conclusions}

The following effects of zirconium additions on $\mathrm{X} 11 \mathrm{CrNiMo12}$ steel are presented in the paper:

Zirconium additions refine the non-metallic inclusion size in Al-killed steels. Their size and overall inclusion area is decreased.

The zirconium non-metallic inclusions exhibit the pinning effect, and serve as grain growth, resulting in a finer microstructure.

Zirconium nitrides form at higher zirconium contents, and their formation is attributed to a weakening of the precipitation hardening effect, which is normally observed by carbo-nitride precipitation during tempering.

At higher zirconium contents $(0.07 \%)$, the size of the non-metallic inclusions is increased due to zirconium nitride nucleation on the zirconium oxides, although the total inclusion area stays approximately the same.

Author Contributions: Conceptualization, J.B., M.K. and J.M.; methodology, J.B., M.K., B.Š.B. and J.M.; validation, J.B. and M.K.; investigation, J.B., M.K. and B.Š.B.; writing-original draft preparation, J.B.; writing-review and editing, J.B. and B.Š.B.; visualization, B.Š.B.; supervision, J.M.; project administration, J.B. and M.K.; and funding acquisition, J.B. and M.K. All authors have read and agreed to the published version of the manuscript.

Funding: This research was made as a part of the ČMRLJ research project, co-financed by the Republic of Slovenia and the European Union under the European Regional Development Fund.

Conflicts of Interest: The authors declare no conflict of interest.

\section{References}

1. Bhadeshia, H.K.D.H. Design of ferritic creep-resistant steels. ISIJ Int. 2001, 41, 626-640. [CrossRef]

2. Žužek, B.; Vodopivec, F.; Podgornik, B.; Jenko, M.; Godec, M. Calculation of accelerated stationary creep rate activation energy for a steel microstructure with a uniform distribution of carbide particles. Mater. Tehnol. 2012, 46, 661-664.

3. Žužek, B.; Vodopivec, F.; Jenko, M.; Podgornik, B. Effect of creep strain on creep rate in the temperature range $550-640{ }^{\circ} \mathrm{C}$. Mater. Tehnol. 2014, 48, 545-548.

4. Vodopivec, F.; Kafexhiu, F.; Žužek, B.; Podgornik, B. Glide Stress by Stationary Creep of Tempered Martensite with Polyhedral Particles. Steel Res. Int. 2017, 88. [CrossRef]

5. Vodopivec, F.; Kafexhiu, F.; Žužek, B. Effect of Ferrite Lattice Vacancies on Creep Rate of the Steel X20CrMoV121 in the Range 763-913 K. Steel Res. Int. 2017, 88. [CrossRef]

6. Abe, F. Analysis of creep rates of tempered martensitic $9 \% \mathrm{Cr}$ steel based on microstructure evolution. Mater. Sci. Eng. A 2009, 510-511, 64-69. [CrossRef]

7. Abe, F.; Kern, T.-U.; Visawanathan, R. Creep-Resistant Steels; Abe, F., Kern, T.-U., Visawanathan, R., Eds.; Woodhead Publishing and Maney Publishing: Cambridge, UK, 2008.

8. Mapelli, C. Non-metallic inclusions and clean steel. Metall. Ital. 2008, 100, 43-52.

9. Shin, J.H.; Park, J.H. Formation Mechanism of Oxide-Sulfide Complex Inclusions in High-Sulfur-Containing Steel Melts. Metall. Mater. Trans. B Process Metall. Mater. Process. Sci. 2018, 49, 311-324. [CrossRef]

10. Da Costa E Silva, A.L.V. The effects of non-metallic inclusions on properties relevant to the performance of steel in structural and mechanical applications. J. Mater. Res. Technol. 2019, 8, 2408-2422. [CrossRef]

11. Long, M.; Zuo, X.; Zhang, L.; Chen, D. Kinetic modeling on nozzle clogging during steel billet continuous casting. ISIJ Int. 2010, 50, 712-720. [CrossRef]

12. Singh, S.N. Mechanism of Alumina Buildup in Tundish Nozzles During Continuous Casting of Aluminum-Killed Steels. Metall. Trans. 1974, 5, 2165-2178. [CrossRef]

13. Li, Y.; Wan, X.L.; Lu, W.Y.; Shirzadi, A.A.; Isayev, O.; Hress, O.; Wu, K.M. Effect of Zr-Ti combined deoxidation on the microstructure and mechanical properties of high-strength low-alloy steels. Mater. Sci. Eng. A 2016, 659, 179-187. [CrossRef]

14. Baker, T.N. Role of zirconium in microalloyed steels: A review. Mater. Sci. Technol. 2014, 31, $265-294$. [CrossRef] 
15. Bizyukov, P.V.; Giese, S.R. Effects of Zr, Ti, and Al Additions on Nonmetallic Inclusions and Impact Toughness of Cast Low-Alloy Steel. J. Mater. Eng. Perform. 2017, 26, 1878-1889. [CrossRef]

16. Wang, C.; Wang, Z.; Wang, G. Effect of Hot Deformation and Controlled Cooling Process on Microstructures of Ti-Zr Deoxidized Low Carbon Steel. ISIJ Int. 2016, 56, 1800-1807. [CrossRef]

17. Janis, J.; Karasev, A.; Nakajima, K.; Jönsson, P.G. Effect of Secondary Nitride Particles on Grain Growth in a Fe-20 mass\% Cr Alloy Deoxidised with Ti and Zr. ISIJ Int. 2013, 53, 476-483. [CrossRef]

18. Suito, H.; Karasev, A.V.; Hamada, M.; Inoue, R.; Nakajima, K. Influence of Oxide Particles and Residual Elements on Microstructure and Toughness in the Heat-Affected Zone of Low-Carbon Steel Deoxidized with Ti and Zr. ISIJ Int. 2011, 51, 1151-1162. [CrossRef]

19. Zhang, L.; Kannengiesser, T. Austenite grain growth and microstructure control in simulated heat affected zones of microalloyed HSLA steel. Mater. Sci. Eng. A 2014, 613, 326-335. [CrossRef]

20. Du, Y.; Wu, K.M.; Cheng, L.; Li, Y.; Isayev, O.; Hress, O. Effect of Zr-Ti deoxidisation on the hydrogen-induced cracking of X65 pipeline steels. Mater. Sci. Technol. 2016, 32, 728-735. [CrossRef]

21. Koležnik, M.; Burja, J.; Šetina Batič, B.; Nagode, A.; Medved, J. De-oxidation of Pk942 steel with Ti and Zr. Mater. Tehnol. 2017, 51, 1031-1036. [CrossRef]

22. Suito, H.; Ohta, H.; Morioka, S. Refinement of Solidification Microstructure and Austenite Grain by Fine Inclusion Particles. ISIJ Int. 2006, 46, 840-846. [CrossRef]

23. Wang, P.; Lu, S.P.; Xiao, N.M.; Li, D.Z.; Li, Y.Y. Effect of delta ferrite on impact properties of low carbon 13Cr-4Ni martensitic stainless steel. Mater. Sci. Eng. A 2010, 527, 3210-3216. [CrossRef]

24. Burja, J.; Koležnik, M.; Župerl, Š.; Klančnik, G. Nitrogen and nitride non-metallic inclusions in steel. Mater. Tehnol. 2019, 53, 919-928. [CrossRef]

25. Wasai, K.; Mukai, K. Thermodynamic analysis on metastable alumina formation in aluminum deoxidized iron based on Ostwald's Step Rule and classical homogeneous nucleation theories. ISIJ Int. 2002, 42, 467-473. [CrossRef]

26. Ohta, H.; Suito, H. Dispersion Behavior of MgO, ZrO2, Al2O3, CaO-Al2O3 and MnO-SiO2 Deoxidation Particles during Solidification of Fe-10mass\%Ni Alloy. ISIJ Int. 2006, 46, 22-28. [CrossRef]

27. Karasev, A.; Suito, H. Quantitative evaluation of inclusion in deoxidation of Fe-10 mass pct Ni alloy with $\mathrm{Si}$, Ti, Al, Zr and Ce. Metall. Mater. Trans. B 1999, 30, 249-257. [CrossRef]

28. Karasev, A.V.; Suito, H. Nitride Precipitation on Particles in Fe-10mass\%Ni Alloy Deoxidized with Ti, M $(\mathrm{M}=\mathrm{Mg}, \mathrm{Zr}$ and $\mathrm{Ce})$ and Ti/M. ISIJ Int. 2009, 49, 229-238. [CrossRef]

29. Burja, J.; Šuler, B.; Nagode, A. Effect of ageing temperature on reverse austenite content in AISI 630 stainless steel. Materwiss. Werksttech. 2019, 50, 405-411. [CrossRef]

30. Sigworth, G.K.; Elliott, J.F. The Thermodynamics of Liquid Dilute Iron Alloys. Met. Sci. 1974, 8, $298-310$. [CrossRef]

(C) 2020 by the authors. Licensee MDPI, Basel, Switzerland. This article is an open access article distributed under the terms and conditions of the Creative Commons Attribution (CC BY) license (http://creativecommons.org/licenses/by/4.0/). 